\title{
The Effectiveness of Application of Regional Regulations Number 7 of 2015 concerning Non-Smoking Areas in Ogan Komering Ulu District Health Office
}

\author{
Efektivitas Penerapan Peraturan Daerah Nomor 7 Tahun 2015 Tentang Kawasan Tanpa \\ Rokok di Kantor Dinas Kesehatan Kabupaten Ogan Komering Ulu \\ Heri Fachrizal, Eko Nurmardiansyah, Suwandi \\ email: Fachry.fachry.heri@gmail.com
}

Health Law Master Program, Soegijapranata Catholic University of Semarang

\begin{abstract}
Effectiveness is a state that the extent to which shows the plan has been achieved. Smoking is a personal right of everyone, on the other hand, the need to respect and respect the rights of others to breathe fresh air free of cigarette smoke. When a smoking activity has violated a person's right to breathe clean air has begun to be neglected then the Government must be present to solve the problem. The negative impact of exposure to secondhand smoke is not only on active smokers but also has a major impact on people around who become passive smokers. Government Regulation NO. 7 The year 2015 has explained that the office is as a place of society or workers who come every day to work and later as one of the pioneers of the No Smoking Area. This study aims to determine the effectiveness of the application of local regulations at the Office of Health Office of OKU Regency

The method in this research is sociological juridical, with analytical descriptive. Respondents are ten rooms and employees working in the room. The resource persons in this study were the head of OKU Regency Health Office and the sub-division Head

The results of this study indicate regional regulation NO. 7 The year 2015 on Non-Smoking Areas that have been applied at the Office of Health Office OKU less effective. The results of this study also show that many employees found smoking in the area of No Smoking Area.
\end{abstract}

Keywords: Effectiveness, Local Regulation, Area Without Cigarette 


\section{PENDAHULUAN}

Undang-Undang Dasar Negara Republik Indonesia Tahun 1945 (UUD 1945) mengatur dan melindungi kesehatan sebagai Hak Asasi Manusia (HAM). Amanat ini tertuang dalam Pasal $28 \mathrm{H}$ ayat (1) yang memuat, "setiap orang berhak sejahtera lahir dan batin, bertempat tinggal dan mendapatkan lingkungan hidup yang baik dan sehat serta berhak memperoleh pelayanan kesehatan".Sesuai hak atas kesehatan tersebut diatur lebih lanjut dengan Undang-Undang Nomor 36 Tahun 2009 tentang Kesehatan yang selanjutnya dalam tulisan ini disebut Undang-Undang Kesehatan mengatur bahwa "Setiap orang berhak mendapatkan lingkungan yang sehat bagi pencapaian derajat kesehatan". Tanpa lingkungan yang sehat, seseorang dapat terjangkit penyakit baik menular maupun tidak menular. Hal ini kemudian menjadikan seseorang tidak sederajat secara kondisional dan tidak akan mampu memperoleh hak-haknya yang lain.

Sebagaimanaketentuan Pasal 162 Undang-Undang Nomor 36 Tahun 2009tentang Kesehatan mengatur bahwa:

Upaya kesehatan lingkungan ditujukan untuk mewujudkan kualitas lingkungan yang sehat, baik fisik, kimia, biologi, maupun sosial yang memungkinkan setiap orang mencapai derajat kesehatan yang setinggi-tingginya.

Untuk menilai tingkatpelayanan kesehatan maka dari itu harus memperhatikan dan meningkatkan dua aspek yaitu promotif dan preventif. Pelayanan kesehatan secara promotif adalah pelayanan yang dilakukan dengan cara meningkatkan, manaikan derajat kesehatan sedangkan pelayanan kesehatan secara preventif adalah pelayananyang silakukan dengan cara mencegah atau menghindari penyebab terjadi suatu penyakit. Sehingga bentuk pelayanan kesehatan bukan hanya ada pada fasilitas pelayanan kesehatan lembaga-lembaga kesehatan saja melainkan juga dalam bentuk-bentuk kegiatan lain, baik yang langsung kepada peningkatan kesehatan dan pencegahan penyakit, maupun yang secara tidak langsung berpengaruh kepada peningkatan kesehatan.Salah satu cara yang dilakukan untuk melakukan mewujudkan dari hidup yang sehat adalah melalui upaya preventif. Pencegahan terhadap penyebab sakit dapat dilakukan dengan memulai hidup sehat serta menghindari faktor-faktor penyebab timbulnya penyakit. Semakin banyaknya penyakit yang muncul dan sering mengakibatkan kematian, menjadikan setiap orang perlu mencegahnya dan bergaya hidup sehat. Gaya hidup sehat itu bisa kita ciptakan dengan cara membuat lingkungan hidup disekitar bebas dengan faktor-faktor pencetusnya, salah satunya adalah menghindari asap-asap polusi, salah satunya yaitu asap dari rokok.

Rokok masih menjadi persoalan yang tidak bisa dilepaskan begitu saja di Indonesia. Data dari Kementerian Kesehatan menunjukan prevalensi perokok di Indonesia pada usia 15 tahun meningkat sebesar 36,3\% dibandingkan dengan Tahun 1995 yaitu 27\%.' Saat ini Indonesia menempati urutan terbesar ketiga di dunia setelah China dan India, dengan proporsi mencapai 35 persen dari total populasi, atau sekira 75 juta jiwa. Belum lagi pertumbuhan prevalensi perokok pada anak-anak dan remaja yang tercepat di dunia, yaitu 19,4 persen. Bahkan menurut data Atlas Pengendalian Tembakau di ASEAN, sebanyak 30 persen sekitar 20 juta anak di Indonesia yang berusia dibawah 10 tahun adalah

\footnotetext{
${ }^{1}$ Berita ini disiarkan oleh Biro Komunikasi dan Pelayanan Masyarakat Kemenkes, "Pemerintah Upayakan Pengurangan Jumlah Perokok Pemula", diakses pada 30 Juli 2017, http://www.depkes.go.id/article/view/17060200002/pemerintah-upayakan-pengurangan-jumlah-perokokpemula-.html
} 
perokok. ${ }^{2}$ Dampak negatif yang dirasakan dari paparan asap rokok tidak hanya pada perokok aktif saja namun juga berdampak besar terhadap orang-orang di sekitar yang menjadi perokok pasif. Dampak kerugian yang disebabkan oleh paparan asap rokok sangat buruk bagi kesehatan, hal ini dimulai dari rusaknya selaput lendir sampai penyakit keganasan seperti kanker. Faktor lain juga dapat disebabkan dari perilaku merokok serta ditemukan dari bahaya secondhand-smoke, yaitu paparan asap rokok yang dihirup oleh perokok tidak aktif (tidakmerokok)yang berada disekitar area perokok.

Berdasarkan Pasal 10 Undang-Undang Nomor 36 Tahun 2009tentang Kesehatan disebutkan bahwa "Setiap orang berkewajiban menghormati hak orang lain dalam upaya memperoleh lingkungan yang sehat, baik fisik, biologi, maupun sosial". Aktifitas merokok pada satu sisi merupakan hak pribadi setiap orang, namun disisi lain perlunya untuk menghormati dan menghargai hak orang lain untuk menghirup udara segar yang bebas dari asap rokok. Ketika aktifitas merokok telah melanggar hak seseorang untuk menghirup udara bersih sudah mulai terabaikan maka pemerintah harus hadir untuk mengatasi masalah tersebut.

Asap rokok yang ditimbulkan oleh perokok aktif sangat berbahaya bagi kesehatan, salah satu solusi menghirup udara bersih tanpa paparan asap rokok yaitu dengan menetapakan area Kawasan Tanpa Rokok. Pasal 115 ayat (2) Undang-Undang Nomor 36 Tahun 2009tentang Kesehatan mengatur: "Pemerintah Daerah wajib menetapkan wilayah Kawasan Tanpa Rokok diwilayahnya". Ketentuan tersebut dijabarkan dengan Peraturan Pemerintah 109 Tahun 2012 tentang Pengamanan Bahan Yang Mengandung Zat Adiktif Berupa Produk Tembakau Bagi Kesehatan dalam Pasal 52 mengatur: "Pemerintah Daerah wajib menetapkan Kawasan Tanpa Rokok diwilayahnya dengan Peraturan Daerah". Berdasarkan ketentuan Pasal 52 Peraturan Pemerintah Nomor 109 Tahun 2012 tentang Pengamanan Bahan Yang Mengandung Zat Adiktif Berupa Produk Tembakau Bagi Kesehatan dari penjelasan diatas, maka tiap daerah mengatur Kawasan Tanpa Rokok dengan Peraturan Daerah Nomor 7 Tahun 2015. Kawasan Tanpa Rokok adalah ruangan atau area yang dinyatakan dilarang untuk kegiatan merokok atau kegiatan memproduksi, menjual, mengiklankan, dan/atau mempromosikan Produk Tembakau.

Penyelenggaraan pengamanan aktivitas merokok bagi kesehatan sebagai upaya agar tidak mengganggu dan membahayakan kesehatan perseorangan, keluarga, masyarakat, dan lingkungan disekitarnya. Maka dari itu Pemerintah dan Pemerintah Daerah wajib mewujudkan Kawasan Tanpa Rokok sebagai upaya mewujudkan lingkungan yang sehat.

Sebagaimana ketentuan Undang-Undang Kesehatan Nomor 36 tahun 2009 dalam Pasal 115 Ayat (1) mengatur bahwa:
a. fasilitas pelayanan kesehatan;
b. tempat proses belajar mengajar;
c. tempat anak bermain;
d. tempat ibadah;
e. angkutan umum;
f. tempat kerja; dan
g. tempat umum dan tempat lain yang ditetapkan.

\footnotetext{
${ }^{2}$ Agregasi Antara, "Miris! Jumlah Perokok Indonesia Terbesar ke-3 di Dunia, Nih Dampaknya”, diakses pada 30 Juli 2017, https://lifestyle.okezone.com/read/2017/05/30/481/1703332/miris-jumlah-perokok-indonesia-terbesar-ke-3-didunia-nih-dampaknya
} 
Pemprov DKI Jakarta adalah contoh daerah yang sukses menerapkan Kawasan Tanpa Rokok. Diawali dengan pertemuan-pertemuan lintas program yang membahas tentang Kawasan Tanpa Rokok di tingkat provinsi, akhirnya disepakati bahwa Dinas Kesehatan DKI Jakarta akan melakukan advokasi kepada Gubernur DKI bersama-sama dengan LM3 (Lembaga Menanggulangi Masalah Merokok). Melalui Peraturan Daerah DKI Nomor 75 Tahun 2005 dan diadakan sosialisasi mulai bulan Februari 2005, kemudian diberlakukan mulai tanggal 6 April 2005. Peraturan daerah ini mengatur mengenai Kawasan Dilarang Merokok di tempat pelayanan kesehatan, tempat proses belajar mengajar, tempat bermain anak, tempat ibadah, angkutan umum, tempat kerja dan tempat umum. Setelah beberapa lama dilakukan sosialisasi, dilakukan monitoring untuk mengetahui seberapa jauh keefektifan peraturan tentang rokok tersebut. ${ }^{3}$

Berdasarkan amanat Undang-Undangbahwa Pemerintah Daerah wajib menetapkan Kawasan Tanpa Rokok di wilayahnya, maka Pemerintah Kabupaten Ogan Komering Ulu mengeluarkan Peraturan Daerah Nomor 7 Tahun 2015 tentang Kawasan Tanpa Rokok. Pada peraturan ini tersirat bahwa perkantoran adalah sebagai tempat masyarakat atau pekerja yang setiap hari datang untuk bekerja dan nantinya adalah sebagai salah sau pelopor Kawasan Tanpa Rokok. Lingkungan perkantoran atau tempat kerja baik di pemerintahan maupun swasta merupakan salah satu area yang termasuk kedalam Kawasan Tanpa Rokok. Upaya yang dilakukan oleh lingkungan perkantoran sebagai lingkungan kerja fisik adalah segala sesuatu yang ada di sekitar para pekerja yang dapat mempengaruhi dirinya dalam menjalankan tugas-tugas yang dibebankan, misalnya penerangan, suhu udara, ruang gerak, keamanan, kebersihan, musik dan lain-lain.4

Berdasarkan pemantauan peneliti di Kantor Dinas Kesehatan Kabupaten Ogan Komering Ulu, seharusnya kantor Dinas Kesehatan menjadi pelopor Kawasan Tanpa Rokok bagi lingkungan perkantoran lainnya di Kabupaten Ogan Komering Ulu sebagai upaya mewujudkan pelaksanaan atas kebijakan tentang pelaksanaan dan penetapan Kawasan Tanpa Rokok di wilayah perkantoran. Melihat penjabaran diatas maka penulis tertarik untuk melakukan penelitian tesis dengan judul "Efektivitas Penerapan Peraturan Daerah Nomor 7 Tahun 2015 Tentang Kawasan Tanpa Rokok Di Kantor Dinas Kesehatan Kabupaten Ogan Komering Ulu".

\section{PERUMUSAN MASALAH}

Berdasarkan latar belakang masalah di atas, maka rumusan masalah dalam penelitian ini yaitu:

1. Bagaimana Efektivitas Penerapan Peraturan Daerah Nomor 7 Tahun 2015 tentang Kawasan Tanpa Rokok di kantor Dinas Kesehatan Kabupaten Ogan Komering Ulu?

2. Bagaimana Pengaruh Faktor Yuridis Dan Sosiologis Terhadap Penerapan Peraturan Daerah Nomor 7 Tahun 2015 tentang Kawasan Tanpa Rokok di kantor Dinas Kesehatan Kabupaten Ogan Komering Ulu?

\footnotetext{
${ }^{3}$ Pusat Promosi Kesehatan Kementerian Kesehatan Republik Indonesia, 2011, Pedoman Pengembangan Kawasan Tanpa Rokok, Jakarta: Kementerian Kesehatan RI, hlm. 44. 4 Alex S.Nitisemito, 2002, Manajemen Personalia Edisi Revisi, Jakarta: Ghalia Indonesia, hlm. 15.
} 


\section{METODE PENELITIAN}

\section{Metode Pendekatan}

Sesuai dengan tujuan dari penelitian hukum ini, maka metode pendekatan yang digunakan adalah penelitian hukum empiris dengan model yuridis sosiologis karena mempunyai obyek kajian mengenai efektivitas penerapan Peraturan Daerah. Perilaku pegawai yang dikaji adalah perilaku yang timbul akibat berinteraksi dengan sitem norma yang ada. Interaksi ini muncul setalah diberlakukanya Perundang-Undangan dan bisa pula dilihat dari perilaku para pegawai sebagai bentuk aksi dalam mempengaruhi pembentukan sebuah ketentuan hukum positif.

Pendekatan yuridis sosiologis adalah penelitian hukum pemberlakuan atau implementasi ketentuan hukum secara in action pada setiap peristiwa hukum tertentu yang terjadi dalam masyarakat. Implementasi secara action tersebut merupakan fakta empiris dan berguna untuk mencapai tujuan yang telah ditentukan oleh negara. ${ }^{5}$ Penelitian aspek yuridis ini adalah berupa ketentuan hukum tentang Efektivitas Penerapan Peraturan Daerah Kawasan Tanpa Rokok dan pemenuhan hak. Aspek sosiologis yang diteliti adalah Efektivitas Penerapan Peraturan Daerah Nomor 7 Tahun 2015 tentang Kawasan Tanpa Rokok di Kantor Dinas Kesehatan Kabupaten Ogan Komering Ulu.

\section{Spesifikasi Penelitian}

Spesifikasi penelitian yang dipergunakan adalah deskriptif analitis yaitu melakukan deskriptif terhadap hasil penelitian dengan data yang selengkap dan sedetail mungkin. Metode deskriptif ini merupakan metode penelitian yang memusatkan perhatian masalah atau fenomena yang bersifat aktual pada saat penelitian dilakukan. Sehingga dalam penelitian ini, peneliti kemudian menggambarkan fakta-fakta tentang masalah yang diselidiki sebagaimana adanya diiringi dengan interpretasi rasional dan akurat. Kondisi lapangan yang sebenarnya menjadi acuan dalam penggambaran selanjutnya, dimana apa yang terjadi dilapangan saat penelitian berlangsung diceritakan dan digambarkan secara lengkap. 6

Metode deskriptif ini sebagai prosedur pemecahan masalah yang diselidiki dengan menggambarkan atau melukiskan keadaan subyek atau obyek penelitian pada saat sekarang berdasarkan fakta-fakta yang tampak atau sebagaimana adanya. Dimana permasalahan dan cara penyelesaianya didudukan dalam persfektif informan, dan fungsi peneliti adalah fasilitator yang berusaha menyelami berbagai ketimpangan yang dirasakan informan. Hasil penelitian ini lebih ditekankan pada memberikan gambaran obyektif tentang keadaan sebenarnya dari subyek yang diteliti yaitu efektivitas penerapan Peraturan Daerah Nomor 7 Tahun 2015 tentang Kawasan Tanpa Rokok sebagai bagian dari peraturan di daerah tersebut, serta faktor yuridis dan sosiologis yang berpengaruh pada Efektivitas Penerapan Peraturan Daerah Nomor 7 Tahun 2015 tentang Kawasan Tanpa Rokok di kantor Dinas Kesehatan Kabupaten Ogan Komering Ulu.

\footnotetext{
${ }^{5}$ Abdulkadir Muhammad, 2004, Hukum dan Penelitian hukum, Bandung: Citra Aditya Bhakti, hlm. 134.

${ }^{6}$ Hadari Nawawi, 2001, Metode Penelitian Bidang Sosial, Yogyakarta: Gajah Mada University Press, hlm. 37.
} 


\section{PEMBAHASAN}

\section{Efektifitas Penerapan Perda Nomor 7 Tahun 2015 tentang Kawasan Tanpa Rokok di Kantor Dinas Kesehatan Kabupaten OKU}

Peraturan perundang-undangan baik yang tingkatannya lebih rendah maupun lebih tinggi memiliki tujuan agar seluruh lapisan masyarakat baik itu di tingkat pusat maupun daerah dapat melaksanakan dan menerapkannya secara konsisten tanpa adanya diskriminasi (equality before the law). Negara diselenggarakan tidak atas kemauan semata sang penguasa, tetapi negara diperintah berdasarkan hukum yang sudah dibuat dan disediakan sebelumnya serta penguasa tunduk pada hukum tersebut. ${ }^{7}$ Sedangkan perbuatan pemerintahan menurut Van Vollenhoven dalam Lutfhi Effendi merupakan tindakan yang secara spontan atau atas inisiatif sendiri dalam menghadapi keadaan dan keperluan yang timbul tanpa menunggu perintah atasan dan atas tanggung jawab sendiri demi kepentingan umum. ${ }^{8}$

Salah satunya adalah peraturan perundang-undangan yang disusun oleh Pemda Kabupaten OKU melalui usulan sub bagian Pencegahan dan Pengendalian Penyakit Dinkes Kabupaten OKU ${ }^{9}$, yakni Peraturan Daerah Nomor 7 Tahun 2015 Tentang Kawasan Tanpa Rokok yang memiliki tujuan untuk melindungi kesehatan masyarakat secara umum dari dampak buruk merokok baik secara langsung maupun tidak langsung, membudayakan hidup sehat dan menekan angka pertumbuhan perokok pemula. Adapun perda tersebut merupakan wujud tanggungjawab untuk memenuhi hak setiap orang untuk mendapatkan lingkungan yang sehat dalam hal ini terbebas dari paparan asap rokok. ${ }^{10}$ Hal ini sesuai dengan Pasal 25 PP Nomor 19 Tahun 2003 tentang Pengamanan Rokok Bagi Kesehatan yang menyebutkan bahwa "Pemerintah Daerah wajib mewujudkan kawasan tanpa rokok di wilayahnya".

Masih dalam perda yang sama, menurut Pasal 5 Kawasan Tanpa Rokok meliputi:

a. Fasilitas pelayanan kesehatan;

b. Tempat proses belajar mengajar;

c. Tempat anak bermain;

d. Tempat ibadah;

e. Angkutan umum;

f. Fasilitas olahraga;

g. Tempat kerja; dan

h. Tempat umum dan tempat lain yang ditetapkan; (seperti: hotel, restoran, terminal, pasar, pusat perbelanjaan, minimarket, supermarket, departement store, hypermarket, mall, plaza, pertokoan, tempat wisata, stasiun, dan tempat umum lainnya).

Pada huruf g disebutkan bahwa tempat kerja termasuk ke dalam area Kawasan Tanpa Rokok. Sesuai dengan perda tersebut maka setiap lingkungan perkantoran yang ada di Kabupaten OKU wajib melaksanakan kebijakan tersebut dimana tempat kerja merupakan tempat berlangsungnya kegiatan atau aktivitas para pekerja maka dari itu

\footnotetext{
${ }^{7}$ Satjipto Rahardjo, 2009, Negara Hukum Yang Membahagiakan Rakyatnya, Yogyakarta: Genta Publishing, hlm. 15

${ }^{8}$ Lutfi Effendi, 2003, Pokok-Pokok Hukum Administrati, Malang: Bayumedia Publishing, Hlm. 36.

${ }^{9}$ Sutaryo, Kasi. Pengendalian dan Pencegahan Penyakit Tidak Menular Dinas Kesehatan Kabupaten OKU, Wawancara tanggal 23 November 2017.
} 
lingkungan perkantoran Dinas Kesehatan Kabupaten OKU harus menjadi pelopor terwujudnya KTR.

Kebijakan yang telah dibuat oleh pemerintah baik dari pusat hingga daerah mengenai Kawasan Tanpa Rokok tersebut ternyata tidak sepenuhnya dapat berjalan dengan baik. Pasal 11 ayat (2) Peraturan Daerah Nomor 7 Tahun 2015 Tentang Kawasan Tanpa Rokok menyebutkan bahwa "setiap orang atau badan berkewajiban ikut serta memelihara dan meningkatkan kualitas udara yang sehat dan bersih serta bebas dari asap rokok". Setelah dilakukan penelitian di Kantor Dinkes Kabupaten OKU masih ditemukannya pegawai yang tidak memiliki kesadaran akan kesehatan lingkungan dengan masih melakukan aktifitas merokok di tempat kerja yang secara jelas dilarang berdasarkan Peraturan Daerah Nomor 7 Tahun 2015 Tentang Kawasan Tanpa Rokok. Paparan asap rokok sangat berbahaya bagi kesehatan individu yang tidak merokok (perokok pasif) dan lingkungan kerja itu sendiri.

Berdasarkan hasil wawancara dengan Dedi Wijaya selaku Ka. Bidang Kesehatan Masyarakat Dinas Kesehatan Kabupaten OKU menyatakan bahwa banyaknya pegawai yang merokok di area Kawasan Tanpa Rokok seperti ruang kerja diakibatkan oleh ketidaktersediannya fasilitas bagi perokok. Selain itu beliau juga menambahkan bahwa setelah dilakukan sosialisasi mengenai perda KTR tetapi kesadaran akan merokok tidak pada Kawasan Tanpa Rokok masih juga tidak diindahkan.11

Hak atas lingkungan yang sehat merupakan hak setiap orang khususnya di tempat kerja. Pasal 163 ayat (2) Undang-Undang Nomor 36 Tahun 2009 tentang Kesehatan menyebutkan bahwa "lingkungan sehat mencakup lingkungan permukiman, tempat kerja, tempat rekreasi, serta tempat dan fasilitas umum". Lebih lanjut ayat (3) menyebutkan bahwa lingkungan sehat haruslah terbebas dari unsur-unsur yang menimbulkan gangguan kesehatan, antara lain:

a. limbah cair;

b. limbah padat;

c. limbah gas;

d. sampah yang tidak diproses sesuai dengan persyaratan yanG ditetapkan pemerintah;

e. binatang pembawa penyakit;

f. zat kimia yang berbahaya;

g. kebisingan yang melebihi ambang batas;

h. radiasi sinar pengion dan non pengion;

i. air yang tercemar;

j. udara yang tercemar; dan

k. makanan yang terkontaminasi.

Paparan asap rokok di tempat kerja merupakan bagian dari zat kimia yang berbahaya bagi kesehatan sehingga menjadikan hak atas lingkungan kerja yang sehat menjadi tidak terpenuhi.Hal ini menunjukkan terjadinya ketidakselarasan antara peraturan dengan penerapannya di lapangan dengan masih tidak diindahkannya perda KTR. Sehingga peneliti menilai Peraturan Daerah Nomor 7 Tahun 2015 Tentang Kawasan Tanpa Rokok

${ }^{11}$ Dedi Wiayata selaku Ka. Bidang Kesehatan Masyarakat Dinkes Kabupaten OKU, Wawancara tanggal 24 November 2017. 
tidak berjalan efektif. Ketidakefektifan penerapan perda KTR juga sedikit banyak dipengaruhi oleh:

a. Kurangnya Kesadaran

Kesadaran akan lingkungan yang sehat merupakan bagian dari pembangunan kesehatan dimana hal ini kurang mendapatkan dukungan dari seluruh masyarakat khususnya pegawai Dinas Kesehatan Kabupaten OKU. Hal ini terbukti dengan masih adanya pegawai Dinas Kesehatan Kabupaten yang tetap merokok di lingkungan kerja atau tempat kerja. Kurangnya kesadaran akan lingkungan yang sehat juga dalam hal memberikan kesempatan kepada mereka yang tidak merokok untuk mendapatkan udara bersih juga secara tidak langsung telah melanggar hak orang lain.

b. Tidak tersedianya Fasilitas Merokok

Kantor Dinas Kesehatan Ogan Komering Ulu dalam pelaksanaan Kawasan Tanpa Rokok saat ini belum menyiapkan area khusus tempat merokok dan baru dalam perencanaan pembangunan fasilitas khusus bagi perokok. Keberadaan fasilitas khusus perokok sangat penting untuk mendukung pelaksanaan KTR sehingga para perokok dapat merokok pada tempatnya tanpa mengganggu hak orang lain untuk mendapatkan udara yang sehat.

c. Minim Pengawasan

Meskipun telah diatur mengenai pengawasan pelaksanaan Kawasan Tanpa Rokok di tempat kerja oleh SKPD yang di bidang ketenagakerjaan ${ }^{12}$ tetapi fungsi pengawasan tersebut rupanya masih belum dilaksanakan dengan baik.

d. Pemberian Sanksi

Masih banyaknya pegawai Dinas Kesehatan Kabupaten OKU yang masih merokok di Kawasan Tanpa Rokok juga dikarenakan tidak tegasnya pemberian sanksi bagi yang melanggar perda tersebut. Tidak adanya pemberian sanksi yang telah dituangkan dalam Pasal 24 dan 25 Peraturan Daerah Nomor 7 Tahun 2015 Tentang Kawasan Tanpa Rokok mulai dari peringatan tertulis, sanksi administratif hingga sanksi pidana tidak juga menjadikan para perokok di Kantor Dinas Kabupaten OKU untuk tidak merokok di area tempat kerja.

Keempat faktor diatas saling berkaitan satu sama lain yang menurut Edward III dalam Budi Winarno terdapat dua karakteristik utama pada penerapan kebijakan yaitu Standart Operational Procedure (SOP) dan fragmentasi. SOP merupakan perkembangan dari tuntutan internal akan kepastian waktu, sumber daya serta kebutuhan penyelenggaraan dalam organisasi kerja yang kompleks dan luas. Adapun prosedur kerja digunakan untuk mengatasi keadaan umum berbagai sektor publik atau swasta sehingga dengan SOP yang jelas pelaksanaan dapat dioptimalkan dari segi waktu dan tindakan pegawai agar seragam dan merata. ${ }^{13}$ Pada penerapan PERDA KTR di Dinas Kesehatan Kabupaten OKU ternyata belum diikutin dengan pembuatan SOP sebagai acuan dasar tetapi hanya sebatas surat edaran dan sosialisasi berdasarkan perintah atasan. Adapun bentuk pengawasan yang dilakukan hanya berupa melakukan pengecekan tanpa adanya tindak lanjut terkait diberlakukannya program KTR. Meskipun bentuk pengawasan yang dilaksanakan belum sesuai aturan yang ada tetapi hal ini juga cukup memberikan

\footnotetext{
${ }^{13}$ Budi Winarno, 2005, Kebijakan Publik: Teori dan Proses, Yogyakarta: Media Pressindo (Anggota IKAPI), hlm. 150.
} 
kesadaran kepada para pegawai Dinas Kesehatan Kabupaten OKU untuk mematuhi aturan tersebut. ${ }^{14}$

Karakteristik kedua dari struktur birokrasi yang berpengaruh dalam pelaksanaan kebijakan adalah fragmentasi yang merupakan penyebaran tanggungjawab suatu kebijakan kepada beberapa badan yang berbeda sehingga memerlukan koordinasi. Pada umumnya, semakin besar koordinasi yang diperlukan untuk melaksanakan kebijakan, semakin berkurang kemungkinan keberhasilan program atau kebijakan. ${ }^{15} \mathrm{Hal}$ ini juga dikarenakan tidak terlaksananya fungsi pengawasan sebagai bagian dari fragmentasi pembagian tugas dan tanggungjawab SKPD yang telah ditunjuk sebagai pengawas dalam hal ini bagian ketenagakerjaan. Adapun pengawasan yang dilakukan hanyalah sebatas melakukan pengecekan tanpa adanya tindak lanjut untuk pemberian sanksi ataupun teguran. ${ }^{16}$

Tidak adanya SOP dan tidak terbentuknya tim pengawasan sebagai bagian dari penerapan Kawasan Tanpa Rokok di kantor Dinas Kesehatan Kabupaten OKU menjadi penyebab tidak efektifnya penerapan KTR. Efektivitas penerapan erat kaitannya dengan pengawasan yang dilakukan sebagai bentuk untuk memantau sebuah program yang sedang berjalan. Hal ini dibenarkan oleh Ahmad Taqiyuddin selaku Kasi. Hukum dan Kepegawaian Umum Dina Kesehatan Kabupaten OKU yang mengatakan bahwa untuk saat ini pedoman pelaksanaan dan pengawasan terhadap pelaksanaan KTR masih belum berjalan sebagaimana mestinya.17

2. Faktor-Faktor yang Mempengaruhi Penerapan Perda Nomor 7 Tahun 2015 tentang KTR di Kantor Dinas Kesehatan Kabupaten OKU

\section{a. Faktor Yuridis}

1) Faktor Undang-Undang

Landasan Yuridis biasa juga disebut landasan hukum, dasar hukum atau legalitas landasan dasar yang terdapat dalam ketentuan-ketentuan hukum yang lebih tinggi derajatnya. Landasan yuridis dibagi menjadi dua, yaitu: ${ }^{18}$

a) Landasan yuridis yang beraspek formal yaitu ketentuan-ketentuan hukum yang memberi kewenangan kepada badan pembentuknya.

b) Landasan yuridis yang beraspek material adalah ketentuan-ketentuan hukum tentang masalah atau persoalan apa yang harus diatur

Pemerintah Kabupaten Ogan Komering Ulu memiliki Peraturan Daerah Nomor 7 Tahun 2015 tentang Kawasan Tanpa Rokok yang merupakan pedoman pelaksanan aturan diatasnya. Berikut ini adalah faktor yuridis pembentuk Peraturan Daerah Nomor 7 Tahun 2015 tentang Kawasan Tanpa Rokok:

\footnotetext{
${ }^{14}$ Andi Prapto, Ka. Bidang Pencegahan dan Pengendalian Penyakit Dinas Kesehatan Kabupaten OKU, Wawancara tanggal 24 November 2017.

${ }^{15}$ Op.cit., hal. 52.

${ }^{16}$ Paisol, Kasi. Pencegahan dan Pengendalian Penyakit Menular Dinas Kesehatan Kabupaten OKU, Wawancara tanggal 25 November 2017.

${ }^{17}$ Ahmad Taqiyuddin selaku Kasi. Hukum dan Kepegawaian Umum Dina Kesehatan Kabupaten OKU, Wawancara tanggal 26 November 2017.

${ }^{18}$ Amiroeddin Sjarif, 1997, Perundang-Undangan (dasar, jenis, dan teknik membuatnya), Jakarta: PT. Rineka Cipta, HIm. 32.
} 
(1) Pasal 18 ayat (6) Undang-Undang Dasar Negara Republik Indonesia Tahun 1945 yang menjelaskan pemerintah daerah berhak menetapkan peraturan daerah dan peraturan daerah lainnya untuk melaksanakan otonomi dan tugas pembantuan.

(2) Pasal $28 \mathrm{H}$ ayat (1) Undang-Undang Dasar 1945 yang menjelaskan bahwa setiap orang berhak hidup sejahtera lahir dan batin, bertempat tinggal, dan mendapatkan lingkungan hidup yang baik dan sehat serta berhak memperoleh pelayanan kesehatan.

(3) Pasal 162 Undang-Undang Nomor 36 Tahun 2009 tentang Kesahatan yang menyatakan sebagai salah satu upaya kesehatan ditujukan untuk mewujudkan kualitas lingkungan yang sehat, baik fisik, kimia, biologi, maupun sosial yang memungkinkan setiap orang mencapai derajat kesehatan yang setinggi-tingginya.

(4) Pasal 244 ayat (3) Undang-Undang Nomor 23 Tahun 2014 tentang Pemerintah Daerah yang menjelaskan peraturan daerah mulai berlaku dan mempunyai kekuatan mengikat pada tanggal diundangkan, kecuali ditentukan lain di dalam peraturan daerah yang bersangkutan.

(5) Pasal 49 Peraturan Pemerintah Nomor 109 tahun 2012 tentang Pengamanan Bahan Yang Mengandung Zat Adiktif yang menjelaskan Dalam rangka penyelenggaraan pengamanan bahan yang mengandung Zat Adiktif berupa Produk Tembakau bagi kesehatan, Pemerintah dan Pemerintah Daerah wajib mewujudkan Kawasan Tanpa Rokok.

(6) Pasal 50 ayat (1) Peraturan Pemerintah Nomor 109 Tahun 2012 tentang Pengamanan Bahan Yang Mengandung Zat Adiktif yang menjelaskan Kawasan Tanpa Rokok sebagaimana dimaksud dalam Pasal 49 antara lain:
a) fasilitas pelayanan kesehatan
b) tempat proses belajar mengajar
c) tempat anak bermain
d) tempat ibadah
e) angkutan umum
f) tempat kerja

(7) Pasal 50 ayat (4) Peraturan Pemerintah Nomor 109 Tahun 2012 tentang Pengamanan Bahan Yang Mengandung Zat Adiktif yang menjelaskan tempat umum dan tempat lain yang ditetapkan. Pimpinan atau penanggung jawab tempat sebagaimana dimaksud pada ayat (1) wajib menerapkan Kawasan Tanpa Rokok.

(8) Pasal 51 ayat (1) Peraturan Pemerintah Nomor 109 Tahun 2012 tentang Pengamanan Bahan Yang Mengandung Zat Adiktif yang menjelaskan Kawasan Tanpa Rokok sebagaimana dimaksud dalam Pasal 50 huruf $f$ dan huruf g menyediakan tempat khusus untuk merokok. 
(9) Pasal 52 Pemerintah Nomor 109 Tahun 2012 tentang Pengamanan Bahan Yang Mengandung Zat Adiktif yang menjelaskan Pemerintah Daerah wajib menetapkan Kawasan Tanpa Rokok di wilayahnya dengan Peraturan Daerah.

(10) Peraturan Bersama Menteri Kesehatan dan Dalam Negeri Nomor 188/MENKES/PB/2011, Nomor 7 Tahun 2011 tentang Pedoman Pelaksanaan Kawasan Tanpa Rokok yang menjelaskan bahwa setiap asap rokok terbukti membahayakan kesehatan individu masyarakat dan lingkungan sehingga Pemerintah Daerah perlu menetapkan Kawasan Tanpa Rokok dan tindakan perlindungan terhadap paparan asap rokok.

\section{2) Faktor Sanksi}

Menurut Soerjono Soekanto ukuran efektivitas pada elemen pertama adalah: ${ }^{19}$

a) Peraturan yang ada mengenai bidang-bidang kehidupan tertentu sudah cukup sistematis.

b) Peraturan yang ada mengenai bidang-bidang kehidupan tertentu sudah cukup sinkron, secara hirarki dan horizontal tidak ada pertentangan.

c) Secara kualitatif dan kuantitatif peraturan-peraturan yang mengatur bidangbidang kehidupan tertentu sudah mencukupi.

Penerbitan peraturan-peraturan tertentu sudah sesuai dengan persyaratan yuridis yang ada pada elemen kedua yang menentukan efektif atau tidaknya kinerja hukum tertulis adalah aparat penegak hukum. Dalam hubungan ini dikehendaki adanya aparatur yang handal sehingga aparat tersebut dapat melakukan tugasnya dengan baik. Kehandalan dalam kaitannya disini adalah meliputi keterampilan profesional dan mempunyai mental yang baik. Menurut Soerjono Soekanto bahwa masalah yang berpengaruh terhadap efektivitas hukum tertulis ditinjau dari segi aparat akan tergantung pada hal berikut: ${ }^{20}$

1) Sampai sejauh mana petugas terikat oleh peraturan-peraturan yang ada.

2) Sampai mana petugas diperkenankan memberikan kebijaksanaan.

3) Teladan macam apa yang sebaiknya diberikan oleh petugas kepada masyarakat.

Sampai sejauh mana derajat sinkronisasi penugasan-penugasan yang diberikan kepada petugas sehingga memberikan batas-batas yang tegas pada wewenangnya.

Pada Peraturan Daerah Nomor 7 Tahun 2015 tentang Kawasan Tanpa Rokok tertuang didalamnya,

Pasal 24 ayat (1) menjelaskan bahwa:

Pimpinan atau penanggung jawab KTR dapat dikenakan sanksi berupa:

a. peringatan tertulis

b. penghentian sementara kegiatan dan/atau

c. pencabutan izin

\footnotetext{
${ }^{19}$ Soerjono Soekanto, 2008, Op.Cit. hlm. 82.

${ }^{20}$ Soerjono Soekanto, 2008, Ibid, hlm. 82.
} 
Pada pasal 24 ayat (3) menjelaskan bahwa:

"Sanksi sebagaimana dimaksud pada ayat (2) diberikan oleh Bupati atau Pejabat yang berwenang."

Pasal 25 menjelaskan bahwa:

"Setiap orang yang merokok di tempat atau area yang dinyatakan sebagai KTR sebagaimana dimaksud dalam Pasal 8 ayat (1), dipidana dengan pidana kurungan paling lama 3 (tiga) hari atau denda paling banyak Rp. 500.000,00 (lima ratus ribu rupiah)".

Pasal 26 menjelaskan bahwa:

Setiap orang atau badan yang mempromosikan, mengiklankan, menjual, dan/atau membeli rokok di tempat atau area yang dinyatakan sebagai KTR sebagaimana dimaksud dalam Pasal 8 ayat (2), dipidana dengan pidana kurungan paling lama 7 (tujuh) hari atau denda paling banyak Rp.5.000.000,00 (lima juta rupiah).

Pasal 27 menjelaskan bahwa:

Setiap orang / badan yang menjual produk tembakau kepada anak sebagaimana dimaksud dalam Pasal 8 ayat (5) dipidana dengan Pidana kurungan paling lama 3 (tiga) hari atau denda paling banyak Rp. 500.000,00 (lima ratus ribu rupiah).

Pasal 28 menjelaskan bahwa:

"Setiap pengelola Kawasan Tanpa Rokok yang tidak melakukan pengawasan internal, membiarkan orang merokok, tidak menyingkirkan asbak atau sejenisnya, dan tidak memasang tanda tanda dilarang merokok di tempat atau area yang dinyatakan sebagai KTR sebagaimana dimaksud dalam Pasal 9 huruf a, huruf $b$, huruf $c$, dan huruf $d$, dipidana dengan pidana kurungan paling lama 15 (lima belas) hari atau denda paling banyak Rp. 10.000.000,00 (sepuluh juta rupiah)".

Sanksi yang tertuang dalam Peraturan Daerah Nomor 7 Tahun 2015 tentang Kawasan Tanpa Rokok sudah jelas akan tetapi untuk tindakan pemberian sanksisanksi kepada pegawai kantor Dinas Kesehatan yang melanggar tidak diberikan,hal ini yang menyebabkan banyaknya terjadi pelanggaran-pelanggaran dikantor Dinas Kesehatan Kabupaten Ogan Komering Ulu.

Membicarakan tentang efektivitas hukum berarti membicarakan daya kerja hukum itu dalam mengatur dan atau memaksa masyarakat untuk taat terhadap hukum. Hukum dapat efektif jikalau faktor-faktor yang mempengaruhi hukum tersebut dapat berfungsi dengan sebaik-baiknya. Ukuran efektif atau tidaknya suatu peraturan perundang-undangan yang berlaku dapat dilihat dari perilaku masyarakat. Suatu hukum atau peraturan perundang-undangan akan efektif apabila warga masyarakat berperilaku sesuai dengan yang diharapkan atau dikehendaki oleh atau peraturan perundang-undangan tersebut mencapai ujuan yang dikehendaki, maka efektivitas hukum atau peraturan perundang-undangan tersebut telah dicapai. 
Menurut Soerjono Soekanto memprediksi patokan efektivitas elemen-elemen tertentu dari prasarana. Prasarana tersebut harus secara jelas memang menjadi bagian yang memberikan kontribusi untuk kelancaran tugas-tugas aparat di tempat atau lokasi kerjanya. Adapun elemen-elemen tersebut adalah:21

1) Prasarana yang telah ada apakah telah terpelihara dengan baik.

2) Prasarana yang belum ada perlu diadakan dengan memperhitungkanangka waktu pengadaannya.

3) Prasarana yang kurang perlu segera dilengkapi.

4) Prasarana yang rusak perlu segera diperbaiki.

5) Prasarana yang macet perlu segera dilancarkan fungsinya.

6) Prasarana yang mengalami kemunduran fungsi perlu ditingkatkan lagi fungsinya.

Fasilitas yang berwujud sarana dan prasarana bagi aparat pelaksana di dalam melakukan tugasnya. Sarana dan prasarana yang dimaksud adalah prasarana atau fasilitas yang digunakan sebagai alat untuk mencapai efektivitas hukum..

Pada Pasal 6 ayat (1) menjelaskan bahwa:

Khusus KTR yang berada di tempat kerja, tempat umum dan tempat lainnya sebagaimana dimaksud dalam Pasal 5 huruf $g$ dan huruf $\mathrm{h}$ dapat menyediakan tempat khusus untuk merokok.

Pada kantor Kantor Dinas Kesehatan Kabupaten Ogan Komering Ulu sudah ada area Kawasan Tanpa Rokok, akan tetapi untuk ruangan merokok itu sendiri belum disediakan dan masih dalam tahap perencanaan. Hal ini yang menyebabkan banyaknya terjadi pelanggaran yang disebabkan oleh pegawai kantor Dinas kesehatan Kabupaten Ogan Komering Ulu.

\section{3) Faktor pengawasan}

Menurut Soerjono Soekanto yaitu bahwa faktor-faktor yang menghambat efektivitas penegakan hukum tidak hanya terletak pada sikap mental aparatur penegak hukum seperti hakim, jaksa, polisi dan penasihat hukum akan tetapi juga terletak pada faktor sosialisasi hukum yang sering diabaikan. Ada beberapa elemen pengukur efektivitas yang tergantung dari kondisi masyarakat, yaitu: ${ }^{22}$

1) Faktor penyebab masyarakat tidak mematuhi aturan walaupun peraturan yang baik.

2) Faktor penyebab masyarakat tidak mematuhi peraturan walaupun peraturan sangat baik dan aparat sudah sangat berwibawa.

3) Faktor penyebab masyarakat tidak mematuhi peraturan baik, petugas atau aparat berwibawa serta fasilitas mencukupi

Pada efektivitas penerapan tentang KTR di Kantor Dinkes ternyata masih ditemukan pelanggaran meskipun peraturan sudah sangat baik tetapi aparatur penegak dalam hal ini SATPOL-PP tidak menjalankan fungsinya dalam

\footnotetext{
${ }^{21}$ Soerjono Soekanto, 2008, Ibid, hlm. 82 .

${ }^{22}$ Serjono Soekanto, 2008, ibid, hlm. 82.
} 
memberikan, tindakan dan pengawasan. Pasal 19 ayat (1) Peraturan Daerah Nomor 7 Tahun 2015 tentang Kawasan Tanpa rokok menjelaskan bahwa "Satuan Polisi Pamong Praja berkoordinasi dengan SKPD lainnya wajib melakukan inspeksi dan pengawasan ke seluruh gedung di wilayah kerjanya". Selanjut pada ayat (2) disebutkan bahwa "Satuan Polisi Pamong Praja selanjutnya melaporkan hasil inspeksi dan pengawasan kepada Bupati".

Dengan demikian tidak terlaksananya fungsi pengawasan dan penindakan terhadap pegawai Dinas Kesehatan yang melakukan pelanggaran dengan merokok pada area Kawasan Tanpa Rokok menyebabkan terhambatnya efektivitas penerapan Peraturan Daerah Kawasan Tanpa Rokok di Dinas Kesehatan Kabupaten Ogan Komering Ulu.

\section{b. Faktor Sosiologis}

Teori efektivitas hukum menurut Soerjono Soekanto adalah bahwa efektif atau tidaknya suatu hukum ditentukan oleh lima faktor, yaitu: ${ }^{23}$

1) Faktor hukumnya sendiri (Undang-Undang) yaitu suatu kebijakan atau tindakan yang tidak sepenuhnya berdasar hukum merupakan sesuatu yang dapat dibenarkan sepanjang kebijakan atau tindakan itu tidak bertentangan dengan hukum.

2) Faktor penegak hukum yaitu penegakan kebenaran tanpa kejujuran adalah suatu kemunafikan. Dalam kerangka penegakan hukum oleh setiap lembaga penegakan hukum (inklusif manusianya) keadilan dan kebenaran harus dinyatakan, harus terasa dan terlihat, harus diaktualisasikan

3) Faktor sarana atau fasilitas yang mendukung penegakan hukum yaitu faktor yang dapat menunjang untuk terbentuknya efektifitas penerapan.

4) Faktor masyarakat yaitu untuk mencapai kedamaian di dalam masyarakat. Setiap warga masyarakat atau kelompok sedikit banyaknya mempunyai kesadaran hukum, persoalan yang timbul adalah taraf kepatuhan hukum, yaitu kepatuhan hukum yang tinggi, sedang, atau kurang.

5) Faktor kebudayaan yaitu mengatur agar manusia dapat mengerti bagaimana seharusnya bertindak, berbuat, dan menentukan sikapnya kalau mereka berhubungan dengan orang lain

\section{PENUTUP}

KESIMPULAN

Berdasarkan penelitian yang telah dilaksanakan di Dinas Kesehatan Kabupaten Ogan Komering Ulu, peneliti menyimpulkan bahwa:

a. Penerapan Perda Nomor 7 Tahun 2015 tentang Kawasan Tanpa Rokok di Kantor Dinas Kesehatan Kabupaten Ogan Komering Ulu saat ini dinilai tidak efektif. Ketidakefektifan penerapan Peraturan Daerah KTR ini sebagian besar disebabkan oleh kurangnya kesadaran para pegawai Dinas Kesehatan akan pentingnya lingkungan kerja yang sehat dan terbebas dari paparan asap rokok serta menghargai hak pegawai lainnya yang tidak

\footnotetext{
${ }^{23}$ Ibid, Hlm. 82.
} 
merokok sebagai bentuk profesionalisme dalam bekerja. Selain itu tidak efektifnya penerapan Peraturan Daerah ini juga sedikit banyak diakibatkan karena kurangnya pengawasan dan pemberian sanksi yang tegas bagi pegawai yang melanggar, dan juga tidak tersedianya fasilitas khusus bagi mereka yang merokok.

b. Adapun faktor yuridis yang mempengaruhi penerapan Perda Nomor 7 Tahun 2015 tentang Kawasan Tanpa Rokok di Kantor Dinas Kesehatan Kabupaten Ogan Komering Ulu, yakni adanya sanksi administratif berupa peringatan lisan maupun tertulis dan sanksi pidana berupa kurungan penjara atau denda administrasi terhadap para pegawai yang melanggar. Sedangkan faktor sosiologis yang mempengaruhi penerapan Peraturan Daerah Nomor 7 Tahun 2015 tentang Kawasan Tanpa Rokok di Kantor Dinas Kesehatan Kabupaten Ogan Komering Ulu, yakni adanya faktor hukumnya, faktor penegak hukum, faktor sarana dan fasilitas, faktor kebudayaan, faktor msayarakat.

\section{SARAN}

a. Bagi pengambil kebijakan

Dengan berlakunya peraturan daerah nomor 7 tahun 2015 tentang kawasan tanpa rokok, para aparatur sipil negara perlu menyambut baik serta lebih mengoptimalkan dengan adanya peraturan yang telah di keluarkan oleh daerah tersebut, sedangkan aparatur sipil negara lainnya juga dapat mendukung upaya dalam mengindahkan peratuan yang telah dibuat oleh daerah tersebut.

b. Bagi tenaga kesehatan dan sarana pelayanan

Keyakinan/kepercayaan masyarakat terhadap pelayanan akan semakin memudar apabila setiap pihak yang terkait dalam pelayanan kesehatan tidak menciptkan kondisi yang aman dan nyaman. Perkantoran akan menjadi tempat yang nyaman jika semua aturan yang telah diterapkan atau diberlakukan sudah bisa di taati dengan baik tanpa adanya pelangaran dan para mengikuti standar sesuai dengan peraturan daerah nomer 7 tahun 2015, dan di butuhkan ruang untuk merokok agar para perokok aktif bisa merokok ditempat tersebut.

c. Bagi peneliti selanjutnya

Untuk mengukur sejauh mana harapan masyrakat atas pelayanan kesehatan, dengan berjalannya Peraturan DaerahNomor 7 Tahun 2015 tentang KTR yang telah di berlakukan maka peneliti menyarankan untuk peneliti yang selanjutnya agar lebih memahami dan mengembangkan isu-isu yang ada pada saat akan datang. 


\section{DAFTAR PUSTAKA}

BUKU

Lutfi Effendi, 2003, Pokok-Pokok Hukum Administrati, Malang: Bayumedia Publishing.

MuhammadAbdulkadir, 2004, Hukum dan Penelitian hukum, Bandung: Citra Aditya Bhakti.

Nawawi Hadari, 2001, Metode Penelitian Bidang Sosial, Yogyakarta: Gajah MadaUniversity Press.

Nitisemito Alex S., 2002, Manajemen Personalia Edisi Revisi, Jakarta: Ghalia Indonesia

Rahardjo Satjipto, 2009, Negara Hukum Yang Membahagiakan Rakyatnya, Yogyakarta: Genta Publishing.

SjarifAmiroeddin, 1997, Perundang-Undangan (dasar, jenis, dan teknik membuatnya), Jakarta: PT. Rineka Cipta.

Soekanto Soerjono, 1985, Efektivitas Hukum dan Peranan Saksi, Bandung: Remaja Karya.

Winarno Budi, 2005, Kebijakan Publik: Teori dan Proses, Yogyakarta: Media Pressindo (Anggota IKAPI).

\section{INTERNET}

(Lengkap) Biro Komunikasi dan Pelayanan Masyarakat Kemenkes, "Pemerintah Upayakan Pengurangan Jumlah Perokok Pemula", diakses pada 30 Juli 2017, http://www.depkes.go.id/article/view/17060200002/pemerintah-upayakanpengurangan-jumlah-perokok-pemula-.html

(Lengkap) Agregasi Antara, "Miris! Jumlah Perokok Indonesia Terbesar ke-3 di Dunia, Nih Dampaknya", diakses pada 30 Juli 2017, https://lifestyle.okezone.com/read/2017/05/30/481/1703332/miris-jumlah-perokokindonesia-terbesar-ke-3-di-dunia-nih-dampaknya

Pusat Promosi Kesehatan Kementerian Kesehatan Republik Indonesia, 2011, Pedoman Pengembangan Kawasan Tanpa Rokok, Jakarta: Kementerian Kesehatan Rl, hlm. 44.http://webcache.googleusercontent.com/search?q=cache:KwNmJrtVN5cJ:www.d epkes.go.id/resources/download/promosi-kesehatan/pedomanktr.pdf $+\& c d=1 \& h l=i d \& c t=c l n k \& g \mid=i d$

\section{UNDANG-UNDANG}

RI, Undang-Undang Dasar Republik Indonesia Tahun 1945 Pasal 28 H Ayat (1)

RI, Undang-Undang Nomor 36 Tahun 1999 tentang Hak Asasi Manusia.

RI, Undang-Undang Nomor 36 Tahun 2009 Tentang Kesehatan.

RI, Undang-Undang Nomor 32 Tahun 2012 tentang Pengelolaan Lingkungan Hidup

RI, Undang-Undang 32 Tahun 2009 tentang PPLH

RI, Undang-Undang Nomor 23 Tahun 2014 tentang Pemerintah Daerah 
RI, Peraturan PemerintahNomor 19 Tahun 2003 Tentang Pengamanan Rokok Bagi Kesehatan

RI, Peraturan PemerintahNomor 109 Tahun 2012 tentang Pengamanan Bahan yang Mengandung Zat Adiktif berupa Produk Tembakau Bagi Kesehatan

RI, Peraturan Daerah Nomor 7 Tahun 2015 tentang Kawasan Tanpa Rokok

RI, Peraturan Bupati Nomor 8 Tahun 2016 tentang Petunjuk Pelaksanaan RI, Peraturan Daerah Nomor 7 Tahun 2015 tentang Kawasan Tanpa Rokok

RI, Instruksi Menteri Kesehatan Republik Indonesia Nomor 459/MENKES/INS/VI/1999 Tentang Kawasan Bebas Rokok Pada Sarana Kesehatan

RI, Keputusan Bersama Menteri Kesehatan dan Menteri Dalam Negeri Republik Indonesia No.188/MENKES/PB/I/2011 tentang Pedoman Pelaksanaan Kawasan Tanpa Rokok

RI, Instruksi Menteri Kesehatan No. 84/MENKES/Inst/II/2002 tentang Kawasan Tanpa Rokok di Tempat Kerja dan Sarana Kesehatan 